\title{
The role of preyer and good deeds in the (re)modelling of the christian family
}

Gavril TRIFA*

Abstract: One of the most frequent questions that arise in the educational area both in schools and the mass media is related to the role of education within the family in the process of forming new generations of students. The present paper starts from one of the fundamental factors in family education, namely the formative value of prayer. It presents the ideal image of the family, founded on the divine commandments and blessed by the Saviour, as the one in Cana Galilee. Because the family is, theologically speaking, a space of Christian perfection, the role of prayer is to support the continuous process of modelling and remodelling the person, including the relationships between family members, through a continuous personal effort sustained by the work of the divine grace.

Keywords: Bible, faith, family, prayer, formative environment.

\section{Prayer, in spirit and in truth"}

One of the most frequent questions arising in the educational sphere, both in the specific school environment and in the mass media, is related to the education received in the family as part of the development of a new generation of students. The present paper starts from one of the factors which

${ }^{*}$ Reader PhD, Priest, West University of Timişoara. 
represent the foundation of family education, namely the formative value of prayer. It also presents the ideal image of family - established in light of the divine commandments and blessed by the Saviour, as was the family in Cana Galilee. As family is, theologically speaking, a space of Christian perfection, the role of prayer is to support the on-going process of modelling and remodelling the individual, including the understanding and assuming of trials and sufferings through a continuous personal effort supported by divine grace.

Prayer - said either in common or individually within the family - represents one of the most important means for family members to maintain and develop their religiousness. Through prayer the individual talks to God, worships Him, asks for His help, and thanks Him for the blessings bestowed upon him/her. Therefore, prayer is valuable as long as it is spoken "in spirit and in truth", i.e. with a pure heart and with all one's might, acknowledging the Truth in the true faith: "God is a Spirit: and they that worship him must worship him in spirit and in truth" (John 4:24). Christ the Saviour offered as an example the heartfelt prayer of the tax collector, who, with a broken and humble heart, "standing afar off" in the temple, "smote upon his breast, saying, God, be merciful to me a sinner"(Luke 18:13). In other words, for prayer to rise towards God, it must be joined with humility, the only mood which enables us to see our sinfulness, "for every one that exalteth himself shall be abased; and he that humbleth himself shall be exalted"(Luke 18:14).

\section{Prayer and family "life"}

If family is so necessary to the inner transformation of the individual, all the more so does the family, in its entirety, need this 
means of ascending towards God, who bestows upon it His holy grace. As a result of persistent prayer (individual prayer but also in common), God blesses the marriage, makes it ever stronger, making the spiritual gifts from the Holy Spirit blossom in its midst. Christ the Lord promised that "[f]or where two or three are gathered together in my name, there am I in the midst of them" (Matthew 18:20), thus showing that $\mathrm{He}$ is present in a more special way near those who do His will and work in His name.

Moreover, family prayer becomes stronger and must remain in contact with the prayer of the entire Christian community of God's Church. The Holy Scripture shows us how the Christians' prayer for St. Peter led to his miraculous release from prison with the help an angel of God's: "The common prayer of the Christians in Mary's house had the power to undo the chains which Peter was tied in in prison, with a guard on his right and a guard on his left; it was impossible to imagine for a human being that he could escape from behind locked gates guarded also on the outside; still, God's angel wakes the prisoner from his sleep, guides him and takes him out through miraculously opening doors" 1 . The power of prayer resides in the spouses' union of love and life, as sanctified through the Holy Mystery of Matrimony. "If the common prayer of a few people - connected only by origin and faith - can do so much, all the more will be done by the common prayer of the husband and his wife, with whom he forms one body and soul, and with the children who are part of the same perfect unity sealed by the mystery of matrimony. How zealously and in one thought, kneeling in complete faith, with a humble heart, will they ask the Heavenly Father for the forgiveness of their sins, for cleanliness, and for the purging of bad habits"'.

${ }^{1}$ Tiberiu Gh. DÂRLEA, Căsătoria şi viaţa mistică (Marriage and mystical life),

Bucharest, Lumina Publishing House, 1995, p. 95.

${ }^{2}$ Ibidem, p. 97. 
In the Old Testament the most telling example of family faith and prayer is included in the Book of Tobit, which describes the relationship between the two spouses Tobias and Sara. They used to pray together and their relationship was characterized by an exemplary spiritual cleanliness even for the time of the New Covenant: "And after that they were both shut in together, Tobias rose out of the bed, and said, Sister, arise, and let us pray that God would have pity on us. Then began Tobias to say, Blessed art thou, $\mathrm{O}$ God of our fathers, and blessed is thy holy and glorious name for ever... And now, O Lord, I take not this my sister for lust but uprightly: therefore mercifully ordain that we may become aged together. And she said with him, Amen" (Tobit 8:4-5, 7-8). Thus, it was through prayer and clean God-blessed life that the two banished the demon wanting to separate them.

What this Biblical story tells us is that, in the family where prayer is said with piety and regularity, the spirit of separation and other sins has no power. The common family prayer can gather together, in the morning and at night, the family members who have been apart during the day because of daily worries or problems; it keeps alive the awareness of one's dependence on the other, but it also creates a state of peace and quiet so necessary to the family; it raises family life to higher spheres, brings household peace and coats the family strivings with priestly dignity, relying on universal priesthood that all Christians have (Keppler M. Freude).

St. Gregory of Nyssa regarded the common family prayer as the safest keeper of the sanctity of married life and loyalty; it represents the song of joy when children are born, it is the people's true strength in all life's troubles, and it is also the sweetest consolation at the moment of death, as it creates peace with God. Writers like Marko I. Rupnik and Sorin Cosma believe that it is family prayer that deepens and strengthens the spouses' love; it is a progressive openness towards the other, going all the way to acknowledging a presence that supports one's wish for the other to 
accomplish his goal with the one praying. "Prayer argues for an awareness of fidelity and stability. Furthermore, the two people are each other's company before God, each one feels what the other's relationship to God is. Slowly, gradually, prayer will enter and define their love. Thus, prayer will help the two to gradually understand that they are made for married love and to receive this love as a mission entrusted onto them by God so that love itself can emerge into the world through them"3. Through prayer the spouses will see things in a new light and will notice their deepest meaning, thus managing to overcome more easily the unpleasant and difficult moments of this life.

In terms of spiritual life, prayer is the highest expression of God's love, since the one who loves God cannot help praying, talking to Him. Through prayer the individual mystically becomes one with God, so that he can say: "...not I, but Christ liveth in me: and the life which I now live in the flesh I live by the faith of the Son of God, who loved me, and gave himself for me"(Galatians 2:20).

Within the family, common prayer creates a spiritual atmosphere of cleansing fire against the sins of all family members, as well as of strengthening grace to develop virtues. In this respect, St. Nilus of Sinai says: "Pray firstly to be purified of passions, secondly to be freed from ignorance and forgetfulness, and thirdly to be delivered from all temptation and forsaking. Seek in prayer only righteousness and the kingdom, that is virtue and knowledge - and all the rest 'shall be added unto you' (Matthew 6:33)". (St. Nilus of Sinai 1981) Enumerating the spiritual gifts of whole-hearted prayer, St. John Climacus (1959:122) says that "[p]rayer by reason of its nature is the converse and union of man with God, and by reason of its action upholds the world and brings

3 Sorin COSMA, Spiritualitate şi misiune creştină în contextul actual (Spirituality and Christian mission today), Arad, The Publishing House of „Aurel Vlaicu” University, 2013, p. 238. 
about reconciliation with God; it is the mother and also the daughter of tears, the propitiation for sins, a bridge over temptations, a wall against afflictions, a crushing of conflicts, work of angels, food of all the spiritual beings, future gladness, boundless activity, the spring of virtues, the source of graces, invisible progress, food of the soul, the enlightening of the mind, an axe for despair, a demonstration of hope, the annulling of sorrow, ...the mirror of progress, the realization of success, a proof of one's condition, a revelation of the future, a sign of glory."

Common prayer brings man and woman together in a communion of grace. By earnestly practicing prayer (either individually or together with others), family members will in time attain what the Church Fathers have called "the prayer state", which is defined as a passion-free state of the soul that constantly thinks of the spiritual heights of faith. Moreover, family members have the duty to pray, knowing that above all it is God's will, as St. Theophan the Recluse has shown: "What you want for your family life leave unto God, praying in earnest but always saying you are ready to receive whatever God wants to send you, even if it is not easy"4. It is through all these that prayer becomes the way or method of moral religious education, and its value is acknowledged by the official documents for the discipline of religion in Romania ${ }^{5}$.

\section{Fasting and good deeds - in support of the prayer}

Fasting is an important means by which the body becomes humble and is helped to defeat its own passions, while the soul is

${ }^{4}$ St. TheOPHAN the Recluse, Sfaturi inţelepte (Sensible advice), Galaţi, Egumeniţa Publishing House, 2006, p. 413.

5 Dorin OPRIŞ, Dimensiuni creştine ale pedagogiei moderne (Christian dimensions of modern pedagogy), Bucharest, Editura Didactică şi Pedagogică, 2012, p. 124-144. 
cleansed of all evil and gets more easily closer to God. Moderation in eating, which the Christian is encouraged to apply during the fast periods, must be joined with spiritual humility, the only one that can truly do away with temptation. In this respect, St. John Climacus (1959:63) says: "He who attempts to stop this war by temperance, and by that alone, is like a man who has the idea of escaping the sea by swimming with one hand. Join humility to temperance, because without the former the latter is useless." St Basil the Great, a great theologian and teacher of the Church $^{6}$ explains that the fast was established in heaven, but as Adam and Eve had transgressed the command of fasting (not eating from the tree of the knowledge of good and evil), they were banished. Thus, in order for us to attain heaven and salvation, we must obey the command of fasting: "Fasting [...] was prescribed in Paradise. It was the first commandment that Adam received: 'Of the tree of the knowledge of good and evil ye shall not eat.' (Genesis 2:17) Through the words 'ye shall not eat' the law of fasting and abstinence is laid down. If Eve had fasted from the tree, we would not now be in need of this fast. 'They that be whole need not a physician, but they that are sick.' (Matthew 9:12)"”.

Our Saviour Himself fasted for forty days and nights in the wilderness of Carantania, showing to us that, without fasting in body and spirit, we cannot defeat our passions and the devil's power. Therefore, He tells His Apostles, who were unable to cure a lunatic son, that "this kind goeth not out but by prayer and fasting." (Matthew 17:21). In a similar way, St. Aphrahat the Persian Sage argues that "[p]ure fasting is highly acceptable

\footnotetext{
${ }^{6}$ Vasile CREȚU, „Sfầntul Vasile cel Mare, o mare lumină a Bisericii (St. Basil the Great, a great light of the Church)", în Almanah bisericesc, Buzău, Publishing House of the Archbishopric of Buzau and Vrancea, 2011, p. 130-132.

${ }^{7}$ Ibidem.
} 
before God, and it is kept as a treasure in heaven. It is a weapon against the Evil One, and a shield which receives the arrows of the Adversary".

By fasting Christian family retains divine peace, which is so necessary for a harmonious life among family members, their fellow beings and God. St. Gregory Palamas ${ }^{9}$ discusses the connection between fasting, moderation and peace: "Fasting and self-control are a double wall of defence and whoever lives within them enjoys great peace, like someone inside Jerusalem, for the name Jerusalem means peace."

A special role to the family's spiritual ascent is played by the common reading of holy books and meditating on their messages. By reading the Bible and other spiritual books, the Christian cleanses his mind and heart of everything evil and sinful, and receives the words of the Word, which will support the Christian on the good path in life and help him get to know God and His work better. St. Gregory Nazianz explains that, by getting to know God, one can eventually praise Him and desire unity with Him.

Among the good deeds required from a Christian family are the welcoming of strangers and almsgiving. The Book of Genesis (18:1-16) describes how patriarch Abraham welcomed God Himself, who showed Himself to him as three angels at the oak tree in Mamvri. St. John Chrysostom highlights the patriarch's hospitality and praises him for the fact that, although he did not know at first who was visiting him, he welcomed Him with joy and spirit of self-sacrifice. For this good deed the great patriarch was blessed by the Lord. Jesus Christ talks about the welcoming of strangers as a criterion at the Last Judgment, while He Himself

${ }^{8}$ St. Aphrahat the Persan Sage, „Demonstration III”, in Parisot, J. Aphraatis Sapientis Persae Demonstrationes, in Patrologia Syriaca, Vols. 1 and 2, edited by R. Griffin, Paris, Firmin-Didot, 1907, p. 97.

${ }^{9}$ St Gregory Palamas, The Homilies, Dalton PA, Mount Thabor Publishing, 2009, p. 61. 
identifies with a stranger: "...I was a stranger and ye took me in." (Matthew 25:35) Likewise, St. Paul the Apostle urges Christians to help one another and welcome strangers: “...distributing to the necessity of saints; given to hospitality" (Romans 12:13).

Philanthropy or almsgiving, whether for the body or for the soul, is that good deed by which family members are urged to help their fellow human beings in need; in doing this, they resemble God as the Lord of Mercy for all people. Isaiah, the great prophet of the Old Testament, explains that genuine fasting goes together with almsgiving, and is followed by divine blessing: "Is it not to deal thy bread to the hungry, and that thou bring the poor that are cast out to thy house? when thou seest the naked, that thou cover him; and that thou hide not thyself from thine own flesh? Then shall thy light break forth as the morning, and thine health shall spring forth speedily: and thy righteousness shall go before thee; the glory of the Lord shall be thy rearward. [...] And if thou draw out thy soul to the hungry, and satisfy the afflicted soul; then shall thy light rise in obscurity, and thy darkness be as the noonday" (Isaiah 58:7-8, 10). Prayer thus becomes the way of life, promoting good deeds; for parents, it supports the faith and the family, while for the children, it is a moral religious model.

Commenting on a few quotations from the Scripture, St. John Chrysostom praises almsgiving and recommends it to all Christians: "For [almsgiving] cleanses from sin. For 'give alms, and all things will be clean unto you' (Luke 11:41). This [almsgiving] is a greater thing than sacrifice. 'For I will have mercy, not sacrifice' (Matthew 9:13). This opens the heavens. For 'your prayers and your alms have come up for a memorial before God' (Acts 10:4)... 'For thus were those virgins cast out of the bridechamber; thus were the others brought in' (Matthew 25:1,13). All which things let us consider, and sow liberally, that we may reap in more ample abundance, and attain unto 
the good things to come"10. The necessity of Christian philanthropy may be understood in the context of the material needs of a part of the society we live in. This is what St. Gregory of Nyssa also argued when he interpreted the "Beatitudes" and wrote: "what is mercy and in regard to what is it practiced? And how is he blessed to whom is returned what he gives? For He says, 'Blessed are the merciful, for they shall obtain mercy' (Matthew 5:7). The obvious meaning of the words calls men to mutual charity and sympathy, which are demanded by the capricious inequality of the circumstances of life; for all live not in the same conditions, neither as regards reputation nor physical constitution nor other assets. Life is in many ways divided up into opposites, since it may be spent as slave or as master, in riches or poverty, in fame or dishonour, in bodily infirmity or in good health - in all such things there is division. Therefore the creature in need should be made equal to the one who has a larger share, and that which goes short should be filled by what has abundance; this is the law mercy gives men in regard to the needy"11.

The Christian family can make a habit out of certain religious practices, which will shelter it from the "wounds" of sins and which will enable its members to ascend to God; at the same time, the place where the family live their daily lives must look like a "small Church", where not only can they feel the warmth of interpersonal communion, but which would also inspire a certain religiousness. Religious icons represent priceless adornments in a Christian home, as they convey holy messages by means of imagery; they were blessed with divine grace and

${ }^{10}$ St. John Chrysostom, Homily 50 on Matthew, edited by Kevin Knight, 2009.

Online: http://www.newadvent.org/fathers/200150.htm [Accessed 4.12.2017].

${ }^{11}$ St. GregORY OF NYSSA, "The Lord's Prayer. The Beatitudes”, in Ancient

Christian Writers No.18, edited by Johannes Quasten and Joseph Plumpe,

New York, Paulist Press, 1953, p. 132. 
their purpose is to bring closer to God those who look at them and who zealously worship them. "Somewhere high, in the centre, must be the icon of Christ, as a steadfast reminder for all the household that gentle Jesus must be at the centre of our lives, with his teachings, love, advice and examples of his life" 12 .

There is a specific icon for every family member, according to his/her age and preoccupations. For instance, the "The Workshop in Nazareth" icon urges the family to work, each one having a well-defined role for the use of all; the "the Gentle Shepherd" icon is first of all addressed to the father, as head of the family, urging him to see to the bodily and spiritual nourishment of his household and to steer them towards redemption; the icon representing Virgin Mary, Mother of the Lord, exhorts mothers to raise their children with love and teach them to praise the Lord, while the icon of "The Ten Maidens" prompts young people to choose the right path in life and to always be ready in spirit to meet God.

\section{Conclusions}

Family prayer, whether said individually or in common, together with the light of good deeds represents a votive candle, the symbol of the light of the Lord's resurrection. If, for times of trouble, the individual - like the family - prepares and arms himself with the weapons of light, the family has the possibility of not just surviving but becoming stronger spiritually. Just as the light of the candle illuminates our thoughts and urges us to live in the holy light of grace and good deeds, prayer strengthens and guides us at all times and towards all good things. St. Paul the Apostle exhorts us: "For ye were sometimes darkness, but now are

12 Tiberiu Gh. DÂRLEA, Căsătoria şi viaţa mistică (Marriage and mystical life), Bucharest, Lumina Publishing House, 1995, p. 119. 
ye light in the Lord: walk as children of light: (For the fruit of the Spirit is in all goodness and righteousness and truth)". (Ephesians 5:8-9) Therefore, the cross, the religious icon, and the candle enable the family's prayer to ascend to God, similar to the incense smoke; then the grace of the Holy Spirit is bestowed on them, blessing both the family members and their home, which becomes a small church, part of the big Church. Simultaneously, prayer, fasting, almsgiving, the welcoming of strangers, the reading of spiritual books, as well as religious items in a Christian's home they all turn his family into a genuine school for living to attain the heavenly kingdom. The corner for family prayer, dedicated to holy religious icons, becomes "a space outside the world, outside time, through which man enters the Kingdom of heaven, while still living in this world"13.

\section{References}

1. Cosma, Sorin, Spiritualitate şi misiune creştină în contextul actual (Spirituality and Christian mission today), Arad, The Publishing House of „Aurel Vlaicu” University, 2013.

2. CREȚU, Vasile, ,Sfầntul Vasile cel Mare, o mare lumină a Bisericii (St. Basil the Great, a great light of the Church)", în Almanah bisericesc, Buzău, Publishing House of the Archbishopric of Buzau and Vrancea, 2011.

3. DÂRLEA, Tiberiu Gh., Căsătoria şi viața mistică (Marriage and mystical life), Bucharest, Lumina Publishing House, 1995.

4. LAROCHE, Michel Philippe, Un singur trup - Aventura mistică a cuplului (A single flesh - the mystical adventure of the couple), Timişoara, Amarcord Publishing House, 1995.

5. NiLus OF SINAI, „153 Texts On Prayer”, from Early Fathers From the Philokalia, translated from the Russian text,

${ }^{13}$ Michel Philippe LAROCHE, Un singur trup - Aventura mistică a cuplului (A single flesh - the mystical adventure of the couple), Timişoara, Amarcord Publishing House, 1995, p. 17. 
"Dobrotolubiye," by E. Kadloubovsky and G.E.H. Palmer, eighth edition, London, Faber and Faber Ltd., 1981. Online: http://www.orthodoxprayer.org/Articles_files/Nilus\%20of\%20

Sinai-153\%20Texts.html [Accessed 3.12.2017].

6. OpRIŞ, Dorin, Dimensiuni creştine ale pedagogiei moderne (Christian dimensions of modern pedagogy), Bucharest, Editura Didactică şi Pedagogică, 2012.

7. ST. APHRAHAT THE PERSAN SAGE, „Demonstration III”, in Parisot, J. Aphraatis Sapientis Persae Demonstrationes, in Patrologia Syriaca, Vols. 1 and 2, edited by R. Griffin, Paris, Firmin-Didot, 1907.

8. St. GREGORY OF NYSSA, „The Lord's Prayer. The Beatitudes”, in Ancient Christian Writers No.18, edited by Johannes Quasten and Joseph Plumpe, New York, Paulist Press, 1953.

9. St Gregory Palamas, The Homilies, Dalton PA, Mount Thabor Publishing, 2009.

10. St. John ChrYsostom, Homily 50 on Matthew, edited by Kevin Knight, 2009. Online: http://www.newadvent.org/fathers/200150.htm [Accessed 4.12.2017].

11. ST. JoHn ClimaCUS, Daily Readings for the Great Fast from St. John Climacus' The Ladder of Divine Ascent, translated by Archimandrite Lazarus Moore, Harper \& Brothers, 1959, https://www.parma.org/documents/2017/2/Daily\%20Readings\%20fo r\%20the\%20Great $\% 20$ Fast $\% 20$ \%20Ladder\%20of\%20Divine\%20Ascent.pdf [Accessed 4.12.2017].

12. ST. MAXIMUS THE CONFESSOR, „400 de capete despre dragoste (The four hundred chapters on love)", în Filocalia, nr. 2, Bucharest, Harisma Publishing House, 1993.

13. St. TheOPHAN THE ReCluse, Sfaturi inţelepte (Sensible advice), Galaţi, Egumeniţa Publishing House, 2006.

14. St. BASIL THE GREAT, Homily on fasting (1 to 3), 2011. Online: http://www.johnsanidopoulos.com/2011/03/st-basil-greatshomily-on-fasting-1-of.html [Accessed 4.12.2017].

15. The Bible. King James Version. Online: https://www.bible.com/bible/1/JHN.4.kjv [Accessed 3.12.2017].

16. The Book of Tobit. Online: http://ebible.org/kjv/Tobit.htm [Accessed 3.12.2017]. 